\title{
GENDER AND THE ANALYTICAL JURISPRUDENTIAL MiND
}

\author{
Leslie Green*
}

\section{Law and Jurisprudence}

What can feminism contribute to the study of law? A lot. Feminist theories take a special interest in the role of gender in society and, as far as we know, every society that has a legal system also has a gender hierarchy in which women are dominated by men. ${ }^{1}$ It would be a miracle if the law was not shaped by gender norms. In turn, law supports and helps constitute those norms: the doctrine of feme covert that limited married women's control over property did not merely reflect background misogyny, it gave it shape and force. Feminist scholars have explored such issues in many contexts and found their etiology distressingly similar. This is of academic interest and of practical import: it can help us understand what it is for women to be disadvantaged by law, the ways that happens, and the remedies that might be feasible. These are massively

\footnotetext{
* Professor of the Philosophy of Law, University of Oxford, and Fellow of Balliol College. Professor of Law and Distinguished University Fellow, Queen's University, Kingston, Canada. I thank Chris Essert, Darryl Robinson, the referees for Modern Law Review and, especially, Denise Réaume for careful criticism of earlier versions of this paper.

1 There are many feminisms, but none fail to give gender a central explanatory, and sometimes normative, role. For a philosophically informed discussion of feminism in legal analysis, see Denise Réaume, 'What's Distinctive about Feminist Analysis of Law? A Conceptual Analysis of Women's Exclusion from Law' (1996) 2 Legal Theory 265. For a helpful treatment of feminism in philosophy see Alison Stone, An Introduction to Feminist Philosophy (Cambridge: Polity, 2007).
} 
important contributions to the study of law.

What can feminism contribute to the study of jurisprudence? This is trickier. Of course, if 'jurisprudence' means law-as when we use the term to refer to case law or general principles of law-we already have our answer. But what if 'jurisprudence' means the philosophy of law and, in particular, the philosophy of law in the analytic style dominant throughout the Anglophone world and in many other places as well?

There is plenty of good feminist writing in the normative branches of jurisprudence that overlap moral and political philosophy. ${ }^{2}$ Feminists have tackled issues such as the importance of relationships in morality, free speech and pornography, and the connection between domestic equality and social justice. There is no harmony here, but we are familiar with a range of wellarticulated feminist positions.

Suppose, however, we are thinking of what is usually called 'conceptual' or 'descriptive' jurisprudence. ${ }^{3}$ To assess the relevance of gender here we need

\footnotetext{
2 The literature is vast, but a beginning would have to include: Carole Pateman, The Sexual Contract (Cambridge: Polity Press, 1988); Susan Moller Okin, Justice, Gender, and the Family (New York: Basic Books, 1991); Martha Nussbaum, Sex and Social Justice (Oxford: Oxford University Press, 1999); Cheshire Calhoun, Feminism, the Family, and the Politics of the Closet: Lesbian and Gay Displacement (New York: Oxford University Press, 2000).

${ }^{3}$ I treat these as rough synonyms. Ronald Dworkin held that there is no such thing as descriptive, conceptual jurisprudence: 'Hart's Postscript and the Character of Political Philosophy' (2004) 24 Oxford Journal of Legal Studies 1. If that were true, all conceptual jurisprudence would be normative jurisprudence, and feminism would be relevant to it for the reason I give above. Dworkin's thesis is not relied on in any of the arguments I test here. I examine some of its
} 
to take the question in two stages. General jurisprudence is audacious in ambition. It addresses the nature of law as such, anywhere and everywhere. Its central topics include the existence, identity, and structure of legal systems, the nature of legal norms, the relationships between law and morality, and the dependence of law on social facts. In contrast, special jurisprudence is concerned with conceptual problems about particular kinds of legal systems (e.g. common law, civil law, or Sharia law) or particular doctrines within legal systems (e.g. property, contract, or family law). General and special jurisprudence differ in level of generality - but not only in that. They also differ in the evidence base with which they begin. Law is not itself a technical legal concept; it is part of ordinary social and political thought, and general jurisprudence begins with ordinary (lay) knowledge of law and society. Whether, for example, 'indigenous law' or 'Masonic law' count as law is not determined by how any particular legal system regards the rules of indigenous bands or Freemasons' lodges. Whether according to Australian law indigenous law is 'really' law has no more importance for general jurisprudence than whether, according to Australian law, German law is really law. A social order is law if and only if it has enough features of the core cases of legal systems. ${ }^{4}$ What features those are is not a question that can be

foundations Leslie Green, 'Associative Obligations and the State,' in Justine Burley, ed. Dworkin and his Critics (Oxford: Blackwell, 2004), 267-284.

${ }^{4}$ If indigenous law or Masonic law do not share enough of these features to count as law, they may be nonetheless be importantly like law for various purposes. The idea that general jurisprudence is interested only in law sensu stricto, or that it harbours a secret ambition to police 
answered by consulting the law of some jurisdiction or other. (Which one would we pick?) General jurisprudence is a department of political theory. We should think of its accounts of the nature of law as being similar to theoretical accounts of the nature of markets, states, or political parties.

Leading concepts in special jurisprudence, in contrast, are law-dependent. The evidence base for a theory of restitution need not address 'ordinary' understandings of restitution - there is probably no such thing - nor need the theory accord with some general scheme of what people think they owe each other. It is true that some concepts in special jurisprudence, causation for example, also have a role outside the law, so here we may need to examine relations between causation as the law thinks of it and causation as understood in science or in history. ${ }^{5}$ But special jurisprudence must be centrally interested in, and answerable to, the law-and especially to the law as applied by the courts. This reflects the fact that special jurisprudence takes as its explananda concepts within the law, while general jurisprudence targets the concept of law.

2. Feminism and general jurisprudence

the boundaries around 'law', is simply false. Even John Austin knew that many things that are not law 'are connected [to law] by ties of resemblance and analogy; with which they are further connected by the common name of "laws"'. John Austin, The Province of Jurisprudence Determined, W. E. Rumble, ed. (Cambridge: Cambridge University Press, 1995), 51.

${ }^{5}$ H.L.A. Hart and Tony Honoré, Causation in the Law, 2nd ed. (Oxford: Oxford University Press, 1985). 
Could there be a feminist general jurisprudence? A generation ago, when feminist legal theories began to take shape, we sometimes heard claims such as 'law is male' or 'the state is male in that objectivity is its norm.' ${ }^{6}$ These sound a bit like general theories of law and the state. But are they, really? If law is the male of the species, what is the female? If objectivity is male, is subjectivity female? Any philosopher foolhardy enough to subject slogans like 'law is male' to analytic scrutiny deserves everything he gets. Like 'property is theft', 'law is male' is a searing metaphor that incites people to action, not a cool analysis of the concept of law.

The fact that leading feminist writers of the 1980s and 1990s paid no serious attention to any general theory of law suggests they assumed that feminist theory had no stake in general jurisprudence. ${ }^{7}$ I think they were right. General jurisprudence is 'normatively inert,' and most feminists wanted to be where the action is. ${ }^{8}$ The best feminist theory took up overtly normative positions, backed with careful doctrinal and empirical research to provide the factual premises of the arguments they advanced. Among academic writers,

\footnotetext{
${ }^{6}$ Catharine MacKinnon, 'Feminism, Marxism, and the State: Towards Feminist Jurisprudence,' (1983) 8 Signs 635, at 645.

7 For a sample of their actual concerns, see Ann C. Scales, 'The Emergence of Feminist Jurisprudence: An Essay' (1986) 95 Yale Law Journal 1373; Robin West, 'Jurisprudence and Gender' (1988) 55 University of Chicago Law Review 1, and many of the essays in the two volumes by Frances E. Olsen, ed. Feminist Legal Theory (Dartmouth: Aldershot, 1995).

8 I take the phrase from John Gardner, 'Legal Positivism: 5 1/2 Myths,' (2001) 46 American Journal of Jurisprudence 199. But the point is not unique to positivism; it holds for legal realism, legal naturalism, socio-legal jurisprudence, historical jurisprudence, and all other approaches to law whose aims are descriptive rather than hortatory.
} 
polemics about the sexed character of law proved less productive and ultimately less influential than detailed examinations of gender in the law: in feminist studies of family law, criminal law, discrimination law, and so on. Here, researchers took for granted that the statutes, cases, and practices they scrutinized were authentic legal, or legally-relevant, materials. They did not pause to ask-or, if you like, did not waste time asking-questions like these: Is sexist moralizing from the bench is an application of law or an exercise of discretion? If the principles that best explain and justify settled law harm women is there nonetheless a reason to extend them to unsettled cases? Do men have duties to obey the law that women lack?

Feminist lawyers of the formative generation were not mere casecrunchers or activists, but such theory as mattered for their purposesprincipally, normative theory and social theory-did not include general jurisprudence. And, on the flip side, one would struggle to identify anything distinctively feminist in the general jurisprudence used or developed by writers sympathetic to feminism in legal studies. ${ }^{9}$ By the late 1990s, most scholars had

\footnotetext{
9 Among others who can fairly be counted as feminists of one sort or another: Julie Dickson, Nicola Lacey, Denise Réaume, Connie Rosati, Emily Sherwin, and Seanna Shiffrin. How many of her readers know that Lacey, whose work in socio-legal feminism is indispensable, wrote with precision and insight on the existence conditions for momentary legal systems? (Nicola Lacey, 'The place of the distinction between momentary and non-momentary legal systems in legal analysis,' in W.E. Butler ed., Anglo-Polish Legal Essays (New York: Transnational Publishers, 1982), 15) Or that Denise Réaume, who taught us about culture, discrimination, dignity, also did illuminating work on obligation and law? (Denise Réaume, 'Is Integrity a Virtue? Dworkin's Theory of Legal Obligation' (1989) 39 University of Toronto Law Journal 380.) That such writers
} 
come to see feminist legal studies and analytic jurisprudence as different things: not team-mates, but not competitors either.

How do things stand, thirty years on? There have been decisive steps forward, but also the occasional great leap backward. In her well-regarded book about law and gender, for example, Joanne Conaghan writes, 'the concept of law (to invoke the title of Hart's famous work) has been endlessly interrogated in terms which do not admit the relevance of gender.' ${ }^{10}$ This is no casual remark: Conaghan labours to show that gender has pervasive relevance, not only to law but also to jurisprudence, including (as this quotation affirms) general jurisprudence. '[I]n the legal conceptual framework gender tends to be understood at best as a matter of content not form,' and it is this alleged error that Conaghan strains to correct, by an extended critique of 'The official position...that the idea of law and legal fundamentals are, and certainly ought to be, gender-independent.'11

Now, legal philosophy, unlike law, is a domain without officials, so how could it have any 'official position' on the idea of law? Conaghan's thesis, which I test here, is that shared methodological commitments on the part of (analytic) legal philosophers screen out the relevance of gender to the idea of law. For all

found no incompatibility between general jurisprudence and feminist analysis of law might have given pause to those who think analytic work is ideologically suspect.

${ }^{10}$ Joanne Conaghan, Law and Gender (Oxford: Oxford University Press, 2013), 6.

${ }^{11}$ Conaghan, Law and Gender, 7, 8. 
the vast substantive differences among the jurisprudential views of, say, Hans Kelsen and H.L.A. Hart, Ronald Dworkin and Joseph Raz, John Finnis and Jurgen Habermas, they concur in thinking that the 'idea' of law, or the concept of law, is not in any literal sense 'gendered' because they share a broad commitment to the methods of analytic philosophy.

To know whether that conjecture is plausible, we need to begin by considering what it is it for gender to be relevant to a jurisprudential question. I will assume it is for some position about the nature or role of gender relations to make a jurisprudential thesis more or less plausible, that is, for gender to bear on its truth or acceptability. Compare two problems: (A) You are wondering whether the ideal of equality under the law is satisfied provided existing legal rules are applied constantly, without exception, to all and only those who fall under their terms. That is to presuppose that equality is independent of the content of the law and thus independent of whether that law treats women as it treats men. That would be unacceptable on most feminist views of morality (and on most sane views of morality). So, gender is relevant here. (B) You are instead wondering whether, as Hans Kelsen claimed, municipal and international law form parts of one unified and consistent legal system. ${ }^{12}$ No view about genderwhat constitutes it, what its social importance is, how it shapes law or life-is

\footnotetext{
${ }^{12}$ Hans Kelsen, Pure Theory of Law, M. Knight, trans. (Berkeley: University of California Press, 1967), 328-344.
} 
going to tilt the answer in favour of or against Kelsen's monism. To this question, gender-and, therefore, feminist legal theory -is irrelevant. The difference between (A) and (B) explains why there are feminist theories of legal equality but no feminist theories of legal systems. Likewise, there are feminist theories of discrimination, but no feminist theories of the existence conditions for rules, feminist theories of the family, but no feminist theories of vagueness, and so on.

We can bring the point into focus by imagining a feminist utopia in which all laws, substantive and procedural, all the attitudes underlying and reinforced by them, and all the people creating and administering them cease being sexist. Books about law and gender come to have only antiquarian interest. In that utopia we would have non-sexist law, non-sexist legal institutions, and nonsexist legal officials. But we would still have law. Or does Conaghan intend to deny that when she avers that 'gender is implicated in the very forms of law;'13 that it has a role 'in the construction and formal ordering of law'; and that it is expressed in the 'basic forms and underpinnings of law?'14 These claims supposedly exemplify truths that the analytical tradition in jurisprudence cannot or will not admit. What are they truths about?

An inquiry into 'how law is conceptualized, organized, articulated, and

\footnotetext{
${ }_{13}$ Conaghan, Law and Gender, 5.

${ }^{14} \mathrm{Ibid}, 7$.
} 
legitimated ${ }^{\prime 15}$ cannot show how gender is implicated in 'the very forms of law' since that depends on the content of the law and not on its forms alone. How law is conceptualized, in Conaghan's sense, depends on how people see law, including their fantasies and ideologies. (They may think of law as daddy, or of justice as a woman.) How law is organized and articulated is a function of how the law is used and expressed by its officials and others. How the law is legitimated depends on the sort of stories people tell in defence of the law or its authority. All of these are important but none of them has much bearing on the concept of law. None of them gives us a reason to think that, in fantasy feminist utopia, law would have withered away.

To establish that the very forms of law are 'gendered' would take an explanation of those forms and an account of the sense in which they are masculine (or feminine). Conaghan does not undertake that analysis. Of course, that does not prove it infeasible. We do have a rough model of how to go about that sort of project in Evegny Pashukanis' development of a Marxist theory of law. ${ }^{16}$ First, he explains the basic forms law: Pashukanis says they necessarily include individual rights. Second, he explains how social class is related to control over property. Finally, he argues that the rights that constitute law are

\footnotetext{
${ }^{15} \mathrm{Ibid}, 8$.

${ }^{16}$ Evgeny B. Pashukanis, Law and Marxism: A General Theory, C. Arthur, ed., and B. Einhorn, trans. (1978)
} 
essentially property rights. It follows that law is capitalist, not merely in function or ideology, but in its very form. Pashukanis' theory is liable to objections, but it proceeds in the correct way: from an analysis of the forms of law to an argument connecting those forms to class domination. But the first step, the analytical work, is vital. Seeing this sets Pashukanis apart from many other Marxist theorists. ${ }^{17}$ He warns: 'If...we forgo an analysis of the fundamental juridical concepts, all we get is a theory which explains the emergence of legal regulation from the material needs of society.... Yet legal regulation itself has still not been analyzed as a form. ${ }^{18} \quad$ Feminist jurisprudence calls attention to sexism in the ways people see, use, and defend the law and to the ways these activities emerge in a gender hierarchy; but that is on a par with Marxist attention to 'the emergence of legal regulation from the material needs of society'. Someone who wants to prove that the 'idea' of law, or the 'concept of law', or the 'very forms' of law are gendered needs to go further and achieve for feminism what Pashukanis attempts for Marxism. That would be, not to transcend analytical jurisprudence, but to do it.

\footnotetext{
${ }^{17}$ See Christine Sypnowich, The Socialist Concept of Law (Oxford: Oxford University Press, 1990); Hugh Collins, Marxism and Law (Oxford University Press, 1996). Marxist legal theory went through its own period of hostility to analytic political philosophy, until the 1980s and the emergence of 'analytic Marxism.' Feminist legal theory still struggles to shed its hostility, and for similar reasons.

${ }^{18}$ Ibid., 55.
} 
3. Feminism and concepts in special jurisprudence: an example

In the previous section, I examined the case for thinking feminist legal theory offers an account of the concept of law; now I turn to see how it handles concepts within the law. In other writings, I examined the legal concept of marriage, motivated by legal and moral questions that arise now that same-sex couples can marry. ${ }^{19}$ I do not summarize that work here, though to fix ideas one thesis I defend is that the common law's concept of marriage had less to do with sex than some suppose, and that William Blackstone was essentially correct when he wrote, in 1765, ' Our law considers marriage in no other light than as a civil contract,' approvingly citing Justinian's Digest on the primacy of consensus over concubitus in constituting marriage..$^{20}$

Conaghan strenuously objects to this thesis, which she treats as symptomatic of the errors of the whole analytic approach in special jurisprudence. She says my works offers 'a rare glimpse into how sex/gender is conceived in the analytical jurisprudential mind, ${ }^{21}$ a glimpse that reveals the 'methodological limitations which characterize [all such] jurisprudential analysis,' to wit:

the abstraction of legal concepts from the framework in which they operate

\footnotetext{
${ }^{19}$ Leslie Green, 'Sex-Neutral Marriage,' 64 Current Legal Problems (2011), 1-21.

${ }^{20}$ William Blackstone, Commentaries on the Laws of England, Bk 1 Ch 15.

${ }^{21}$ Conaghan, Law and Gender, 169.
} 
and the tendency to treat them as having a fairly fixed content over time and space; the unarticulated normative prioritization of some features... over others... evidencing the presence of evaluative choices which problematize any claim to be rendering a descriptive or value-neutral account; the overlooking, or at least unexplained disregard, of contraindicative evidence.... ${ }^{22}$

In sum, the allegation is that an analytical approach in jurisprudence fails to detect the significance of gender even in marriage, because the methods of analytic philosophy screen it out: by use of unhistorical abstractions, by a pretense of value-neutrality, and by disregard of empirical evidence.

If this diagnosis were correct, analytical jurisprudence would not merely have 'methodological limitations'; it would be a failure. To suppose legal concepts are unchanging flies in the face of the obvious; the law changes and with it so do some concepts. To think we can describe anything without prioritizing some of its features is to misunderstand the nature of description. To overlook or disregard pertinent evidence is incompetence or dishonesty. Unsurprisingly, I do not accept that I made such blunders. Self-defence may not be enough to get the whole 'analytical jurisprudential mind' off the hook, however. Perhaps I am not prone to these vices though everyone else is; maybe I escaped a bad ${ }^{22} \mathrm{Ibid} ., 176$. 
upbringing. If that were all there were to it the matter would be of little interest, even to me. But that is not all there is to it. If these are endemic vices of analytic jurisprudence (or of 'the analytical jurisprudential mind') then law students would be well advised to stay away from it altogether, especially if they are sympathetic to, or just curious about, a feminist analysis of law. That would be a loss to jurisprudence, and to feminism.

Let us focus for a moment on concepts. Conaghan's claim is that if one abstracts legal concepts from their historical and doctrinal contexts, one inevitably isolates them from gendered contexts. To treat concepts abstractly is to treat them as fixed, whereas they change in ways that respond to, and produce, changes in our ideas about gender. Conaghan illustrates this with reference to my claim that sex and gender pick out different concepts, sex a biological one and gender a social one. She denies this, maintaining that both are social-'social constructions', as some people say - and thus liable to change over time. ${ }^{23}$

Why assume that if we abstract a concept from a particular context of use, or study it at one point in time, we must obscure the role of gender in explaining that concept? Wouldn't that depend on whether gender is, or is not, needed to

\footnotetext{
${ }^{23}$ It is a hard to retrace why Conaghan thinks that, to disprove my claims about marriage, she needs to analyze the relation between sex and gender. Possibly, she thinks an argument showing that sex is not constitutive of marriage can be refuted by arguing that sex is not what it appears to be.
} 
explain that concept, at that time? For example, if we try to analyze the concept woman-in the context of middle-class, twenty-first century Britain-we may have to mention social norms that apply distinctively to adult human females, if woman is, as some think, partly constituted by gender norms. But we would not mention the fact that British women speak fewer languages than Dutch women or are on average 162 centimeters tall. Not everything that is true of most, or even all, instances of $C$ is part of what it is to be $C$. It is not as if the analysis of woman somehow failed to detect relative linguistic incompetence as part of what it is to be a woman. It would have been an error to include it. Why, then, think that if an analysis of some concept in the law, for example, a tort or a treaty, makes no mention of gender it must have missed something needed for an adequate account - and missed it as a result of a defective methodology? We would need an affirmative reason to include it.

Maybe none of this bears on what Conaghan has in mind when she complains about the absence of gender in explanations of the concept of law or concepts in the law. People use the word 'concept' in various ways, and she may be using it differently than those she criticizes. I think it is useful to distinguish concepts (ideas, notions, senses) of things, our words for things (and for concepts), and the very things in question. For example, there is gold, the element that has atomic number 79; there is the concept of gold, an abstract notion that expresses the sense of terms referring to that element and which may rendered in necessary 
and sufficient (or at least typifying) conditions; and finally there is the English word 'gold', which has four letters, brings associations of treasure and sunsets, and translates the Norwegian 'gull' as well as the Irish 'ór'.

If we are interested in the nature of gold, we are unlikely to start by studying our concept of gold, let alone the word 'gold'. On the other hand, to understand the nature of grief, we do need to understand our concept of grief and its relations to nearby concepts (sadness, depression) as well as remote ones (happiness, joy); we may even need to study the meaning and origin of the concept-word 'grief' in English, or its synonyms in other languages. The fruitfulness of conceptual analysis can depend on how anthropocentric and mind-dependent a thing is.

I assume that law is thoroughly anthropocentric and mind-dependent and that analysis of the concept of law reveals things about law. ${ }^{24}$ The same applies to legal relations and entities: crimes, duties, contracts, wills, courts, etc. I also assume that legal concepts can change-has anyone ever denied it? ${ }^{25} \mathrm{New}$ concepts emerge with new bodies of law, as when contract emerges out of assumpsit. Change can also occur when some elements in a cluster-concept alter

\footnotetext{
${ }^{24}$ I am treating this as a sufficient condition for the utility of conceptual analysis in jurisprudence, not as a necessary one.

${ }^{25}$ Can the concept of law itself change? Was there a time when law had a nature other than the one it now has? It is difficult to make sense of the questions, let alone answer them. I do not explore the issues here.
} 
their character or salience: marriage once picked out an indissoluble relationship between two people of different sexes, but no longer. It is a nice question how much can change before we are no longer talking about the same thing. A personal relationship whose duration is legally fixed in advance-a three-year deal, say - is not a marriage; yet the conditions that can terminate a marriage did alter over time. Many jurisdictions now allow 'no fault' divorce. That changed the character of marriage, but it would false (not to say hysterical) to think that it brought an end to marriage. ${ }^{26}$ Ditto with respect to sex difference-or so I argue. The fact that same sex couples can now legally marry is a massive social change, and one that required heroic political efforts. But that does not prove that it brought a massive conceptual change in marriage. Many concept-defining aspects of the institution remained constant, and that is because sex mattered less to (legal) marriage than some think.

Conaghan thinks this way of approaching things loses grip on the essentially 'gendered' character of marriage as an institution oppressive to women (or, I suppose, to at least one ersatz 'woman'). ${ }^{27}$ Following Judith Butler and other

\footnotetext{
${ }^{26}$ Lenore Weitzman argued that no fault divorce was bad for women: Lenore J. Weitzman, The Divorce Revolution: The Unexpected Social and Economic Consequences for Women and Children in America (New York: Free Press, 1985). She never argued that no-fault ended marriage.

${ }^{27}$ Although she seems unaware of it, it follows from Conaghan's view that in a male-male marriage one of the men will have to count as the 'wife'. A similarly disturbing reductionism infects some feminist treatments of pornography. See Leslie Green, 'Pornographies', 8 Journal of Political Philosophy, (2000) 27-52; and Leslie Green, 'Men in the Place of Women, from Butler to Little Sisters,' 44 Osgoode Hall Law Journal (2006) 1-25.
} 
'post-modern' literary critics, Conaghan holds that sex basically is gender, so it follows that she will see gender difference where others do not. But her defence of the sex/gender equivalence is not Butler's. ${ }^{28}$ Conaghan believes sex is gender on the ground that English law sometimes treats sex as gender: 'one way of bringing out this point [i.e. that sex and gender are the same] is to look at how sex and gender have been expressly conceptualized in law. ${ }^{29}$ She offers this example: 'it cannot be contended that sex discrimination in law is confined strictly to discrimination based on biological factors alone. ${ }^{30}$ On this basis, she proposes that sex, like gender, is social: 'the bodies are one thing; the meaning and significance we attach to them another. It is in this sense that it is wrong to assert that our understandings of sex (as opposed to gender) are not also socially and culturally imbued.'31

The thing it is supposedly 'wrong to assert' is, however, not something I ever asserted - nor did Plato, Augustine, Darwin, or Freud. No one denies that views about sex, and even sexual anatomy, can reflect popular understandings

\footnotetext{
28 'If the immutable character of sex is contested, perhaps this construct called 'sex' is as culturally constructed as gender; indeed, perhaps it was always already gender, with the consequence that the distinction between sex and gender turns out to be no distinction at all.' Judith Butler, Gender Trouble: Feminism and the Subversion of Identity (London: Routledge, 1989). Notice that the 'perhaps' leaves lots of room to deny the thesis that the final phrase appears to assert.

${ }^{29}$ Conaghan, Law and Gender, 178.

${ }^{30}$ Ibid., 183.

${ }^{31} \mathrm{Ibid}, 178$.
} 
(and misunderstandings). ${ }^{32}$ My claim is that sex and gender are different, not that notions of sex difference do not reflect social mores, and certainly not that English law always treats sex and gender as different. In fact, what I say about sex and gender cannot illustrate anything about the hazards in the 'abstraction of legal concepts from the framework in which they operate' because I say nothing at all about the legal concepts of sex or gender. The concept I put under scrutiny is the law's concept of marriage. Along the way, I use the ordinary concepts of sex and gender, the ones made more precise in biology, psychology, and sociology. And those are the ones we need. We learn no more about the nature of sex from the fact that the law sometimes treats gender as sex than we would learn about the nature of whales from a Fisheries Act that 'expressly conceptualized' whales as fish. ${ }^{33}$

There is a further, dialectical, point. Feminists who argued for more attention to gender in jurisprudence meant more attention to gender in the ordinary sense of the term, not more attention to gender as 'conceptualized' in English discrimination law or the UK Gender Recognition Act 2014. And they were right to take the broader view. Any legal system's local concept of gender may be profoundly misleading; it may even conceal the full significance of gender

\footnotetext{
${ }^{32}$ See Thomas Laqueur, Making Sex: Body and Gender from the Greeks to Freud (Cambridge, Mass.: Harvard University Press, 1992).

${ }^{33}$ For some reasons why law is so little help in thinking about the realities of 'sex' see Luis Duarte d'Almeida 'Legal Sex' in Leslie Green and Brian Leiter (eds) Oxford Studies in Philosophy of Law, vol. 2 (Oxford: Oxford University Press, 2013) 277.
} 
in the law.

\section{How to distinguish sex and gender}

It is a fair abbreviation of my view to say that gender is 'a social category superimposed upon a sexed body' ${ }^{34}$ Conaghan associates that abbreviation with a hodgepodge of other ideas: that sex is immutable; that our ideas about sexual anatomy are not 'socially inflected', that our attitudes to sex are not socially 'mediated'; and that there is 'a sharp and definitive line ... between nature and nurture.' 35 She rejects those and, with them, any distinction between sex and gender: 'I do not regard the common distinction between sex and gender in terms of nature and nurture (or body and consciousness) as either useful or tenable. Therefore... I will be using "sex" and "gender" loosely and interchangeably...'36

A reasonably clear distinction between sex and gender need not, however, presuppose any of those things. The distinction rests instead on the idea that gender is partly constituted by sex-specific norms and presupposes an independent concept of sex. Gender involves what is conventionally considered appropriate to the sexes. I give this example:

\footnotetext{
${ }^{34}$ Conaghan, Law and Gender, 18.

35 Ibid., 21.

36 Ibid., 22.
} 
To know whether it is a violation of any gender-norm for Robin to wear a dress, drive a truck, or have sex with a man, one first has to know Robin's (presumed) sex. If one can't identify norm-violation and norm-conformity, one cannot identify the norms, and shapeless norms cannot be projected onto something else to give it shape. ${ }^{37}$

Conaghan takes this passage to assert that:

... such arguments [viz. arguments equating sex and gender] are incoherent because unless sex is to some extent objective and fixed, we have no stable reference point for identifying gender norms and no measure for determining gender non-conformity... ${ }^{38}$

No doubt this is why Conaghan suspects that I think sex (or the concept of sex?) is 'fixed' and 'stable', ignoring the possibility that sex/gender could morph over time, in ways that might make it more relevant to jurisprudence. ${ }^{39}$ But the passage under complaint does not say, entail, or presuppose that sex is 'objective' or 'fixed', and nowhere else have I ever claimed that a 'reference point' for gender needs to be stable. Indeed, the fact that gender norms are applied to people in accordance with their presumed sex shows that gender's 'reference point' can be

\footnotetext{
${ }^{37}$ Green, 'Sex-Neutral Marriage,' 4.

${ }^{38}$ Conaghan, Law and Gender, 177.

${ }^{39}$ She never considers the possibility that conceptual change could render sex, or gender, less relevant to jurisprudence.
} 
both subjective and liable to change. The point is important. I claim:

people are generally held to the gender norms of the sex they present; only when they fail to pass are they held to the gender norms of the sex they actually are. (This does not suppose that a person's actual sex is his or her sex at birth; it supposes only there can be a distinction between what someone is and how he is regarded.) One's presumed sex may be determined by gender-presentation, but that does not show that sex is gender. ${ }^{40}$

Compare this with a suggestion in Sally Haslanger's work on the concept of a 'woman'. Haslanger proposes this analysis:

$\mathrm{S}$ is a woman [if and only if] $\mathrm{S}$ is systematically subordinated along some dimension-economic, political, legal, social-and S is 'marked' as a target for this treatment by observed or imagined bodily features presumed to be evidence of a female's biological role in reproduction. ${ }^{41}$

Haslanger follows Catharine MacKinnon, Andrea Dworkin, and many others who emphasize subordination as part of the concept of a woman. The analysis faces objections - is it true that an adult human female who is not 'systematically subordinated' is not a woman? Does a man who wants to become a woman want

\footnotetext{
${ }^{40}$ Green, 'Sex-Neutral Marriage,' 4, note 7.

${ }^{41}$ Sally Haslanger, Resisting Reality: Social Construction and Social Critique (Oxford: Oxford University Press, 2012), 230.
} 
to become a target of subordination? But these are objections to the suggested content of gender-constituting norms; they are not objections to explaining gender as constituted by norms that apply to people in virtue of their actual or supposed sex. Haslanger and I agree on that.

Any literal suggestion that sex is gender would be extravagant. Conaghan concedes as much when she writes that sexual embodiment is 'often the referent for gender-based evaluations and judgments', and acknowledges that human bodies do 'vary anatomically along the lines we generally interpret according to prevailing understandings of sexual difference.' ${ }^{42}$ These comments are all compatible with the kind of distinction between sex and gender that Haslanger or I endorse. An appearance of disagreement is sustained only by the loose talk of 'referents' and 'interpretations'. Gender-based evaluations do not 'refer' to sex; they presuppose beliefs about sex. Suppose someone says, 'Boy George was awful when he was girlish.' The referent of 'Boy George' is George O'Dowd, and the referent of his girlishness is his gender non-conformity. There is no term in this sentence that refers to his sex. The sentence expresses (unjustified) contempt for $\mathrm{O}^{\prime}$ Dowd in virtue of the fact that his girlishness is thought, by the imagined speaker, to be especially awful for someone who is or is held to be male. Our social norms have it that a male should behave and think in certain ways only,

\footnotetext{
${ }^{42}$ Conaghan, Law and Gender, 177.
} 
and these norms constitute gender.

It is also incorrect to hold that sex is merely a classification produced by the ways we 'generally interpret' the 'prevailing understandings' of our anatomy. Plants and animals are sortable into sexes independently of interpretations or understandings because, to put it crudely, things that reproduce sexually are sexed anyway. There were different sexes among the ferns and dinosaurs, long before there were any animals with the cognitive capacity to form interpretations of anatomy or anything else. We may now discover a new organism and be unsure whether it reproduces sexually, and thus unsure whether the individual we found is male or female (or both, or neither). ${ }^{43}$

Gender is different. It is a human projection onto the material world. This explains many familiar facts, including these: gender is much more variable across human history than is sex; children gradually learn gender roles; people can reform gender distinctions. Take a famous example. If you are trying to understand gender in fifth-century Athens, you will need to find out what Athenians (and maybe others) thought fitting conduct for the sexes in that time and place. Among the things you will discover is that in Ancient Greece it was

${ }^{43}$ On 'both' and 'neither' see Joanne Roughgarden, Evolution's Rainbow: Diversity, Gender, and Sexuality in Nature and People, rev. ed. (Berkeley: University of California Press, 2009). Indeterminacy of natal sex in humans is very rare. By comparison, indeterminate gender presentation or 'sense of self' is more common, and not highly correlated with indeterminacy of sex. 'Masculine' and 'feminine' shade into each other more smoothly than do 'male' and 'female'. 
not necessarily thought unmanly for males to have sex with other males. This is so different from gender norms in nineteenth-century England that nervous translators of the classics routinely bowdlerized perfectly clear passages about homosexual love and sex. Yet there was no relevant difference in sexual biology between the boys in Plato's Academy and the boys in Jowett's Balliol.

Must any of this be denied by someone who thinks, 'a clear line between the material world and the ideas and concepts through which we perceive that world cannot really be drawn' ${ }^{44}$ Or-more radically - that, '[T]he discursive juxtaposition of law and the real, whether in terms of correspondence or divergence, belies the fact that law plays a vital role in constituting what we understand as real...'? ${ }^{45}$ No. It is a fallacy to think that without clear lines there can be no clear cases. And even if we go so far as to reject any distinction at all between the world and mind (or law!), it would still not show that sex is gender. It would show they are both mind-dependent. On any plausible metaphysics, some things are mind-dependent, for example, constellations and currency. That does not show that constellations are currency.

What then should we make of the claim that 'law plays a vital role in constituting what we understand as real' $?^{46}$ If it is an empirical conjecture, it

\footnotetext{
${ }^{44}$ Conaghan, Law and Gender, 23.

${ }^{45} \mathrm{Ibid}, 58$.

46 Ibid.
} 
seems implausible. Most people know little of the law and take their cues about what is real from other things: from their own experience, from their peers, from scientists, from priests, from Twitter, and so on. Even a thorough-going metaphysical or linguistic idealist can accept a distinction between the way the world is and the way the world is 'constituted' in law (or in novels, or on Netflix). It would be worrying if someone based her understanding of reality mainly on the law--especially in the domain of sex and gender, where law replicates and produces so much error and superstition.

At points, it is uncertain whether Conaghan intends her thesis about the identity of sex and gender to be taken literally. She warns that she will be using sex and gender 'loosely and interchangeably.' ${ }^{47}$ What started as a substantive disagreement about the bearing of sex on the concept of marriage thus risks becoming no more than a matter of notational variants, or a quirk of dialect. But no one who asserts that sex difference is a necessary feature of marriage will be satisfied by the thought that, since we can speak 'loosely', a gender difference between the partners might suffice. No man who hopes to marry someone of the opposite sex will be happy to discover that his fiancée is a male whose dating profile used the concept woman 'loosely.'

Analytical jurisprudence, like analytic philosophy in general, tries to use ${ }^{47}$ Ibid., 22. 
terms precisely when it can. Admittedly, precision can be a fault, for instance, when it imposes a misleading clarity on an unclarifiably vague subject matter. Are sex or gender such cases? There is no denying that English usage, and English law, does not always distinguish them. In certain contexts, people use 'gender' to mean 'sex'. Sometimes they do so out of prudishness-sex (the classification) and sex (the activity) are embarrassingly homonymic in English. Sometimes they do so because they are trying to sound bureaucratic or academic. Thus we hear talk of 'the gender imbalance of the judiciary' or 'gender discrimination in law firms'. But this does not mark an ambiguity that cannot be resolved or vagueness that cannot be made more precise. People who use 'sex' and 'gender' loosely and interchangeably in such contexts have not lost the capacity to distinguish them when they need to. They do not tell people who suffer depression because their sex does not match their gender identity that they are just conceptually confused. They do not say that appointing four drag queens to the bench would cure the gender imbalance on the Supreme Court.

A final point on law and concepts: If feminists were to treat law's construction of reality as 'vitally' constitutive, they would lose the resources to distinguish the way the world seems to the law and the way the world really is. Along with that, they risk losing another distinction on which the 'analytic jurisprudential mind' famously insists: the difference between law as it is and law as it ought to be. I think reform-minded feminists had better hang on to that 
one.

5. Description and evaluation in jurisprudence

Conaghan's next charge against analytic jurisprudence is that it encourages 'the unarticulated normative prioritization of some features' over others, requiring 'evaluative choices which problematize any claim to be rendering a descriptive or value-neutral account'. ${ }^{48}$ This is not merely an observation; it alleges a fault (a 'methodological limitation'). Since Conaghan makes no suggestion that some other kind of jurisprudence offers value neutrality, the fault can only be one of two kinds. It is either false advertisingpretending to neutrality that is impossible-or else bad values, for example, prioritizing values that lead us to miss the importance of gender in jurisprudence.

Conaghan offers no evidence that I am guilty of false advertising. I have never maintained that accounts of anything of significance in jurisprudence are value-neutral. I do think that many conceptual claims are descriptive-and this applies to my claim that sex is not gender as much as to my claim that, in common law, consummation was not a validity condition for marriage. By 'descriptive' I mean that these are claims about what the concepts of sex and consummation actually are in their respective domains, not claims about what it would be good

${ }^{48}$ Conaghan, Law and Gender, 176. 
for them to be. It does not follow that descriptions involving those concepts are value-neutral: I have long denied that. ${ }^{49}$ 'An actual description of something is not a list of all the facts about it; it is a selection and arrangement of facts that are for some reason taken to be important, salient, relevant, interesting, etc. Every description presupposes, or is made from the point of view of, certain values. ${ }^{50}$

My view is not idiosyncratic; as far as I can see, all contemporary writers in analytic jurisprudence endorse it. But isn't there a live debate about the place of values in jurisprudence? There is indeed, but that is a different debate. I can illustrate it with an example. Suppose a visitor asks how I would describe the English bar, and I reply: 'It is geographically centralized, socially exclusive and systematically sexist'. There are many other facts I could have mentioned instead or as well, so there are 'unarticulated normative prioritizations' behind this reply. But what are they? Without a context there is no way to know, although there are various possibilities, including these:

(a) I think these are bad features of the English bar, so I highlight them as a way of condemning it.

(b) I think these are good features of the English bar, so I highlight them as a way of commending it.

\footnotetext{
${ }^{49}$ Leslie Green, 'The Political Content of Legal Theory,' (1987) 17 Philosophy of the Social Sciences 1, esp. 14-16.

${ }^{50}$ Leslie Green, 'Introduction' to H.L.A. Hart, The Concept of Law 3 $3^{\text {rd }}$ edition (Oxford: Oxford University Press, 2012), xlix.
} 
(c) I think other people think these are bad (or good) features of the English bar, so I highlight them as socially salient, never mind what I think.

(d) I think these features are explanatorily important in understanding other features of the English legal system, never mind the rights and wrongs, or anyone's perceptions of the matter.

The debate about evaluation in legal theory is about whether every description of law must engage the describer's values in (a)-type or (b)-type ways. That thesis is defended by legal philosophers like and Ronald Dworkin and John Finnis. ${ }^{51}$ It is rejected by H.L.A. Hart and by Julie Dickson. ${ }^{52}$ But no one in analytical jurisprudence denies the relevance of values to descriptions in (c)-type or (d)type ways.

Now to the second possibility: that analytical jurisprudence is guilty, not of falsely pretending to neutrality, but of presupposing bad, or unappealing, values. Conaghan thinks some such presupposition underpins my discussion of marriage. One fear is based on a misunderstanding. In describing traditional Anglo-American marriage law, I note that there was no sexual-orientation bar on marrying: gay people could always marry, provided they married other people-

\footnotetext{
${ }^{51}$ Ronald Dworkin, 'Hart's Postscript and the Character of Political Philosophy,' (2004) 24 Oxford Journal of Legal Studies 1; John Finnis, Natural Law and Natural Rights (Oxford University Press, 1979), ch. 1.

52 H.L.A. Hart, The Concept of Law, 240; Julie Dickson, Evaluation in Legal Theory (Oxford: Hart Publishing, 2001)
} 
gay, straight or in-between - of the other sex. Unlike many other writers, I think this fact was conceptually significant. Conaghan takes me to be thereby suggesting that in 'a very technical sense', sex-restricted marriage did not discriminate against lesbians and gay men on grounds of sexual orientation. ${ }^{53}$ That is emphatically not my claim. I expressly say that sex-restricted marriage laws discriminate on grounds of sexual orientation and I explain how they do so. ${ }^{54}$ Moreover, I hold that such discrimination is wrong, and by 'wrong' I mean not that English law treats it as wrong (a (c)-type value relevance), or that treating it as wrong explains important features of English law (a (d)-type value relevance); I think that sexual orientation discrimination really is wrong (that is to say, (a)-type value relevance). I think sexual orientation discrimination is as morally vicious and socially destructive as sex- or race-discrimination. Thus, I here use the term 'discrimination' in its full-blooded, condemnatory, sense and not as a descriptive or technical-legal term. To think sex-restricted marriage laws involve wrongful discrimination does presuppose a lot of things (some of which are argued in this work and some elsewhere), but I cannot see that any of them turn on values a feminist should reject, let alone values that are suspect. ${ }^{55}$

\footnotetext{
${ }_{53}$ Conaghan, Law and Gender, 169.

${ }^{54}$ Commenting on the American case of Goodridge et al. $v$ Department of Public Health, 798 N.E.2d 941, I write, 'the fact that anyone in Massachusetts could, without regard to sexual orientation, use their marital powers to marry someone of a different sex does not begin to show that the marriage law was non-discriminatory." Green, 'Sex-Neutral Marriage,' 13.

${ }^{55}$ For other elements of the argument see Leslie Green, Sexuality, Authenticity, and Modernity,' 8 Canadian Journal of Law and Jurisprudence (1995) 67-82.
} 
The fact that there was no sexual orientation bar to marriage is relevant to a different point entirely. Although the common law of consummation had what I call a 'fixation' with one sex act, the nature of that act shows how little the law cared about sex within marriage. ${ }^{56}$ More than anything else, it is this remark that convinces Conaghan that analytic jurisprudence must be up to no good. She writes, 'This tells us more about what Green thinks of as sex than it communicates about the common law. ${ }^{57}$

What is the implied criticism? To consummate a marriage at common law did not mean to 'have sex'. All sorts of familiar sex acts failed to consummate marriage; the courts were unequivocal about that. Consummation required that a man put his penis inside a woman's vagina, at least for a little while-long enough to please the trier of fact. The law did not require that this act take place between people capable of reproduction. It did not require that the act take place more than once. It did not even require that it be done with the (morally) valid consent of the woman. And importantly, an unconsummated marriage was not void and, though it was voidable, it could be voided only at the request of one of the spouses and only under extremely restrictive conditions.

What does that tell us about what I 'think of as' sex? If we are considering 'sex' the classification, it shows that I think anatomy is relevant to it. If we are

\footnotetext{
${ }^{56}$ Green, 'Sex-Neutral Marriage,' 20.

${ }_{57}$ Conaghan, Law and Gender, 171.
} 
considering 'sex' the activity, it shows the following: First, I t think sexual activity is not exhausted by what the common law counted as marriage-consummating acts. Second, since the law tolerated a sex act that I call rape, it tells us that I hold that the doctrine of consummation was morally deficient. Third, it tells us that I hold that a same-sex couple who, as a matter of natural necessity, cannot perform the consummating act can nonetheless be validly married. As far as I can see, nothing else can be inferred from my claims about sex in marriage. Are any of these views suspect? Should a feminist reject them and hold, instead, that only heterosexual penetrative intercourse conforms to the proper function of sexual activity, or that the marital rape exemption was right, or that same-sex marriages are not marriages at all? Those would undeniably give sex a central role in the concept of marriage; but it is not the role it actually had, and it is not a role a feminist should welcome.

6. Analysis and evidence in jurisprudence

Conaghan's final charge resonates with a criticism familiar from some approaches to the sociology of law and some movements within legal philosophy itself. The methods of analytical jurisprudence, or most of them, seem a priori. Legal philosophy does not spend long hours with the law reports, historical archives, or data sets. Analytical jurisprudence takes its methods from analytic 
philosophy: it examines the nature and structure of the concept of law and legal concepts 'from the armchair', as critics say. These methods are a familiar source of skepticism about analytic philosophy, not only among philosophical 'naturalists' who hope to reconstruct the subject along the lines of a natural science, but also among historically and practically oriented lawyers. ${ }^{58}$ They read in a jurisprudence book that legal systems necessarily have courts, but do not necessarily have legislatures. (All law could be customary.) Then they wonder: how could mere philosophy make that sort of discovery? Wouldn't a generalization about all legal systems - let alone all possible legal systemsrequire mountains of evidence and carefully specified and tested quantitative models?

Yes, any empirical generalization would. But the thesis that legal systems necessarily have courts is not an empirical generalization. It is an explanation of concepts that such a generalization must use. Think of it this way. If you want to do a sociological or historical study of legal systems, you will need to identify them. You cannot just stipulate that you will use legal system 'flexibly and loosely', and then go on to present as some kind of discovery that there are legal systems without courts. That only regurgitates your stipulation. The problem

\footnotetext{
${ }^{58}$ See Brian Leiter, Naturalizing Jurisprudence: Essays on American Legal Realism and Naturalism in Legal Philosophy (Oxford: Oxford University Press, 2007); Morton J. Horowitz, 'Why is AngloAmerican Jurisprudence Unhistorical?' (1997) 17 Oxford Journal of Legal Studies 551.
} 
jurisprudence addresses is a prior one: among the varied forms of social organization with which we are familiar-markets, religions, clubs, anarchic orders, etc. - what distinguishes legal systems? Yet general jurisprudence does not begin - pace Hobbes - with purely postulated premises. Because it is the philosophy of law it presumes enough ordinary knowledge of law to get off the ground, and special jurisprudence presupposes specialist knowledge of laws and legal systems. Nonetheless, jurisprudence is a consumer and not a producer of empirical findings. It does not reveal new facts about any matter; it reveals what matters about familiar facts. To look to analytic jurisprudence to replace history or advocacy would be like looking to Plato's Symposium to understand how sex evolved or how to get a date. On the other hand, if you care about what love is, and why love matters, the Symposium would be a good place to start.

I write, 'The fact that the capacity to marry is already and everywhere neutral with respect to sexual orientation shows how little interest the law takes in sex within marriage. ${ }^{59}$ Conaghan replies, 'Green's conclusion about the insignificance of sex as a core feature of marriage seems so far out of line with the picture of marriage we have encountered up to now as to demand examination. ${ }^{60}$ My argument that a certain kind of sexual activity did not constitute a valid marriage is thus met with the empirical generalization that the regulation of sex

\footnotetext{
${ }^{59}$ Green, 'Sex-Neutral Marriage,' 3.

${ }^{60}$ Conaghan, Law and Gender, 171.
} 
was a historically significant feature of marriage. But latter is not in dispute. The fact that there could, at common law, be a valid marriage between a gay man and a lesbian who never have sex with each other shows exactly what I say it shows: how little the law cared about sex within marriage. Naturally, it does not show 'legal indifference to sexual matters;' ${ }^{61}$ but I never suggest anything so silly. I say the law of consummation was fixated on one sex act. The law would hardly be fixated on something it regards with indifference.

In what sense then might one say that my view amounts to a denial that sex is a 'core feature' of marriage? In two senses only: $(\alpha)$ Sex difference is not conceptually necessary to marriage-so same-sex married couples really are married. ( $\beta$ ) Sexual activity is not necessary to marriage, since a legally valid marriage may be formed, and continue to exist unless voided, without sexual activity between the spouses. There is an important general point here. The necessary features of a legal relation or institution include all of its constitutive features, the features without which it would not be what it is, but they may not include all of its socially important features. Nor are all constitutive features necessarily important. Might I then be correct about the constitutive features of marriage, but have focused on ones that are socially or morally trivial? Not in this case. After all, some people hold that 'conceptually', 'by definition', a

\footnotetext{
${ }^{61}$ Ibid., 172.
} 
marriage must be 'between a man and a woman', the only pair that can perform the marriage-consummating act: $(\alpha)$ denies that. Other people say a sexless marriage is legally void, since the whole point of marriage is to support reproduction: $(\beta)$ denies that. These are not mistakes made by uninformed lay people who have only a partial grasp of the legal concept of marriage, or by lazy students who did not do the reading. They are ideologically motivated errors whose function is uphold a heterosexist ideal of human relationships. That is enough to make $(\alpha)$ and $(\beta)$ important, and important to feminist theory.

Of course, these are not the only important facts about marriage law. It is also important to know how marriage was used to regulate sex, property, and labour. There are excellent historical and sociological writings on these topics, and they are not my targets. There is no need to guess at whom my arguments are actually directed: they are the theorists I mention and, by implication, all others who think that essential nature of marriage is a 'one-flesh union,' constituted by a particular sexual transaction between one person with a penis and one person with a vagina. Through strenuous wishful thinking, such writers find their own religious dogma 'reflected in traditional American and British marriage law' ${ }^{62}$ I try to show why they are wrong, and why their errors matter.

\footnotetext{
62 Robert P. George, 'Public Reason and Political Conflict: Abortion and Homosexuality' (1997) 106 Yale Law Journal 2475. George is only one of several who, in loyalty to a religious ideology, omit facts about marriage as the law sees it. For a penetrating, and patient, critique of George and others see Nicholas Bamforth and David A.J. Richards, Patriarchal Religion, Sexuality, and Gender: A Critique of New Natural Law (Cambridge: Cambridge University Press, 2011).
} 
(Basically, Blackstone was right all along.) Conaghan ignores all this and asserts, 'When we step back and look at marriage in its historical context, we do not see a picture of legal indifference to sexual matters. Rather we see a framework of rules which guaranteed a husband's access-and exclusive access - to the physical person of his wife. ${ }^{63}$ In a final flourish, she declares that marriage 'was all about sex, understood as a hierarchical order based upon male domination and female subjection' ${ }^{64}$

My arguments are consistent with (but do not entail) her bleak view. But when I show how little the common law of marriage cared about sexual activity within marriage, I am not asserting that the law played no role in the domination of women. The law's doctrine of consummation was shot through with sexism of an ugly and obvious kind, in the ways I explain. We are not clear of it even now.

7. Conclusion, warning, and invitation

None of Conaghan's three claims about the 'analytical jurisprudential mind' is sound, and none of her arguments casts any doubt on the diagnosis I offered at the outset: Gender is highly relevant to law because gender norms

\footnotetext{
${ }^{63}$ Conaghan, Law and Gender, 172.

${ }^{64}$ Ibid., 173.
} 
shape the content and application of the law. Gender is relevant to several problems in normative jurisprudence and to some problems in special jurisprudence, though that must be shown piecemeal, in each case. But gender is of no relevance to general jurisprudence for, as far as anyone has shown, there is nothing about 'the very forms of law' that warrants calling them 'gendered', and no answer to leading problems in general jurisprudence depends on any thesis about gender. Finally, the methods of analytical legal philosophy are wellequipped to detect the conceptual role of gender where it exists.

Maybe this will provoke a fresh complaint. If general jurisprudence has so little to learn from feminist theory, perhaps we should stop doing general jurisprudence. Or perhaps people should not write about general jurisprudence unless they also write about law and gender, and in the very same book. Was Hart at fault for developing his defence of gay people against criminal oppression, not in The Concept of Law but in Law, Liberty, and Morality? Should Kelsen have included his defence of a rules-based international order in The Pure Theory of Law? I can think of no reason why. Not every omission is an 'erasure', as they used to say. Conaghan offers this comment on contemporary feminist criticism of earlier feminists:

Not only does this kind of claim often overstate or misrepresent the "errors" of past feminist scholars, it encourages readings of bodies of scholarship 
which were the product of particular times, energies, and concerns against the times, energies, and concerns of later generations. ${ }^{65}$

This is a correct and important point. It applies also to past scholars in analytical jurisprudence. The works of, say, Kelsen or Hart are philosophically rich, intellectually focused, and now also quite old works. They too are the product of particular times, energies and concerns, and their errors are greatly overstated.

In the end, jibes about the 'analytical jurisprudential mind', like jibes about 'the criminal mind' - or for that matter the 'female mind'-express little more than prejudice. As human vices go, an intellectual prejudice is a minor thing. Nonetheless, it will have victims. The most serious casualties will be among beginning law students, especially young feminists curious about things like the social construction of gender, the evaluative character of jurisprudence, the subordination and silencing of women, or social inclusion and legal equality. Will they learn that some of the best thinking on these themes includes work by analytic philosophers, and even analytic legal philosophers? ${ }^{66}$ Will they discover that this work is sensitive to context where relevant, that it is alert to the ways values enter analysis, and that it is literate about social facts? Not if they accept

\footnotetext{
${ }^{65}$ Conaghan, Law and Gender, 125.

${ }^{66}$ For example, see on the following topics: social construction of gender - Sally Haslanger, Resisting Reality: Social Construction and Social Critique (Oxford 2012); evaluation in legal theory Julie Dickson, Evaluation in Legal Theory (Oxford: Hart Publishing, 2001) - subordination and silencing: Rae Langton, Sexual Solipsism: Philosophical Essays on Pornography and Objectification (Oxford: Oxford University Press, 2009); social inclusion and legal equality- Elizabeth Anderson, The Imperative of Integration (Princeton: Princeton University Press, 2010).
} 
Conaghan's caricature. Students told what the 'analytical jurisprudential mind' must think about such issues may not spend time discovering what any particular writer does think. They may feel pressed into building walls against genderexcluding abstractions, smuggled-in values, and empirical biases-unlawful migrants to the empire of law and gender, disguised in nit-picking arguments.

In truth, feminist legal scholars have nothing to fear from the best analytic philosophers working on problems that feminists care about, including the ones I just cited. But to discover whether I am right about that, they will need to read them, and read them while open to the possibility that they may know something worth learning. In jurisprudence as elsewhere, acquaintance is a good solvent of prejudice. It is long past time for feminist jurisprudence to risk meeting the neighbours. It may be pleasantly surprised. 